\title{
KEMAMPUAN FATWA SEBAGAI ALAT MENANGANI EKSTREMISME AGAMA: SATU PENILAIAN
}

\author{
Zaid Hamdani, Rahimin Affandi Abdul Rahim \\ Universiti Malaya, Kuala Lumpur, Malaysia \\ zaidhamdani09@gmail.com
}

\begin{abstract}
A fatwa issued in Islam can be said to be a part of the process of growth and adjustment in Islamic law. It made a mutually interacting relationship between scholars, society and the government. The role of the ulama themselves in this case is very dominant. They must consider all the aspirations and desires of a different group of people in their style and characters. Like the problem of economic development, the political pressure that comes from the same as the government and certain NGOs. The existence of Muslim groups here can already be considered occupying a special space, namely as a lower class community. A fatwa is always issued based on the emergence of one-on-one cases in the community, including the issue that is currently rife is the issue of extremism. In this concise article, we will try to summarize the extent to which the role of a fatwa can deal with the issue of generation.
\end{abstract}

Keywords: Fatwa, Extremism, Shari'ah, Jihad

\begin{abstract}
Abstrak
Sesebuah fatwa yang dikeluarkan dalam Islam ianya dapat dikatakan sebagai bahagian daripada proses pertumbuhan dan penyesuaian dalam hukum Islam.Ia membabitkan hubungan yang saling berinteraksi antara ulama, masyarakat dan kerajaan. Peran ulama itu sendiri dalam hal ini adalah sangat dominan. Mereka harus mempertimbangkan segala aspirasi dan kehendak suatu kelompok masyarakat yang berbeza-beza corak dan karakternya. Seperti masalah pengembangan perekonomian, tekanan politik yang berasal sama ada daripada pihak kerajaan mahupun NGO tertentu. Adapun keberadaan kelompok Muslim di sini sudah dapat dijangkakan menempati ruang khusus iaitu sebagai kelompok masyarakat kelas bawah. Sesebuah fatwa selalunya dikeluarkan berdasarkan munculnya satu-satu kes dalam masyarakat, termasuklah isu yang tengah marak sekarang ini ialah masalah ekstremism/pelampau agama. Dalam artikel ringkas ini akan cuba dirungkai sejauh manakah peran sesebuah fatwa itu dapat menangani isu berbangkit.
\end{abstract}

Kata Kunci: Fatwa, Ekstremism, Shari'Ah, Jihad 


\section{A. Pendahuluan}

Sepertimana sedia maklum bahawa shari'ah ialah merupakan nikmat Tuhan yang sangat berharga yang diturunkan untuk memberikan kesejahteraan kepada umat manusia. ${ }^{1}$ Islam dianggap sebagai al-din (way of life) yang mengandungi peraturan hidup sempurna samaada di dunia mahupun akhirat, ${ }^{2}$ telah menetapkan bahawa elemen perundangan diciptakan ialah untuk difahami dan dilaksanakan dalam kehidupan sehari-hari. ${ }^{3}$

Berasaskan kepada hal tersebut di atas, perlu diwujudkan suatu hubungan yang erat antara pemerintah (agen penguatkuasaan) dan ulama (agen yang mengkaji, menterjemah dan menyusun formula). Peran antara keduanya sungguh sangat signifikan dan tak dapat dipisahkan antara satu dengan lainnya. Mewujudkan saling kerjasama antara keduanya, di mana ulama dengan kesungguhan intelektualnya (kekuatan minda) kemudian diiringi dengan komitmen pemerintah untuk mempastikan kesejahteraan hidup seharian umat dijalankan bersesuaian dengan tuntutan shari'ah. ${ }^{4}$ Oleh yang demikian, berdasarkan hal inilah ulama Islam yang terawal telah membina beberapa institusi khas bagi tujuan merealisasikan kelangsungan shari'ah ke dalam masyarakat, yang terdiri dari: (i) pelaksana dan penguatkuasaan shari'ah Islam (mahkamah shari'ah), (ii) menjawab kemushkilan masalah yang timbul dalam masyarakat dan mewartakannya kepada masyarakat (institusi fatwa), (iii) Mahkamah Rayuan (Mazalim) dan (iv) agensi untuk mempastikan perjalanan aktiviti pentadbiran kewangan negara mengikut peraturan Islam (Hisbah). ${ }^{5}$

Pada peringkat asasnya, meskipun keempat-empat institusi ini mempunyai pendekatan dan gerak kerja yang berbeza-beza, ${ }^{6}$ namun ia sebenarnya merupakan

1 al-Qur'an 7:179 dan lihat juga RamliAwang, Tasammur Rabbani Menurut al-Quran Dan Sunnab (Kuala Lumpur: Hidayah Publisher, 1997), 179-187.

2 al-Quran 3:19 dan 85; 2:256.

3 al-Quran 4: 61 dan 65; 24:46-49 dan lihat juga Rahman, Mohammad Taufiq. Social Justice in Western and Islamic Thought: A Comparative Study of John Rawl's and Sayyid Qutb's Theories of Social Justice. Diss. Jabatan Akidah dan Pemikiran Islam, Akademi Pengajian Islam, Universiti Malaya, 2010.

4 Mahmood Zuhdi Abd. Majid, BidangKuasaJenayahMabkamah Syariah di Malaysia (Kuala Lumpur: Dewan Bahasa dan Pustaka, 2001), 61-71.

5 Auni Haji Abdullah, Hisbah Dan Pentadbiran Negara(Kuala Lumpur: IKDAS,2000), 10-15.

6 MohdDaud Bakar, (1997) "Instrumen Fatwa DalamPerkembangan Perundangan Islam", JurnalSyariah 1, jilid 5, (1997), 2-3. 
ARTIKEL

sebuah mekanisme utama yang menggabungkan suatu bentuk usahasama antara pihak kerajaan dan fuqaha' Islam untuk membangunkan sebuah kerangka penyelesaian masalah Islam terhadap permasalahan hukum amali yang timbul.

Sepanjang sejarah Islam, fatwa telah memainkan perannya yang sangat signifikan dalam menyelesaikan permasalahan umat. Ia berfungsi sebagai alat yang paling berkesan untuk menjawab isu-isu ke-Islaman sekaligus membentuk pemikiran penganut Islam itu sendiri. Autoriti sesebuah fatwa bergantung kepada kredibiliti dan sandaran hukum yang digunapakai sebelum ianya dapat mempengaruhi masyarakat awam.

\section{B. Tinjauan Teori}

\section{Fatwa dan Kajian Ekstremism Islam}

Bila dilihat dari segi fungsinya, fatwa dapat dikembangkan menjadi daya pembangkit semangat jihad umat Islam melawan kuasa besar kaum kafir ataupun menghukum seseorang individu yang secara terang-terangan menyakiti hati dan perasaan umat Islam. Sejarah telah mencatatkan beberapa peristiwa penting berhubungkait dengan fatwa yang dikeluarkan pemerintah atau penguasa terhadap kes-kes pelampau agama. Antaranya ialah:

Pertama, fatwa yang dikeluarkan oleh Ayatollah Rohullah Khomeini pada 14bh Februari 1989 ke atas Salman Rushdie pengarang buku The Satanic Verses. Dalam fatwanya yang disiarkan di Radio Tehran, Ayatollah Khomeini telah menjatuhkan hukuman mati kepada Salman Rushdie dan sesiapa sahaja yang bersubahat dengannya yang menerbitkan buku tersebut. ${ }^{7}$ Fatwanya berbunyi;

In the name of him, the Highest. There is only one God, to whom we shall all return. Inform all zealous Muslims of the world that the author of the book entitled The Satanic Verses -wbich has been compiled, printed and published in opposition to Islam, the Prophet and the Qur'an - and all those involved in its publication who were aware of its contents, are sentenced to death. I call on all zealous Muslims to execute them quickly, where they may be found, so that no one else will dare to insult the Muslim sanctities. God willing, whoever is killed on this path is a martyr. In addition, anyone who has access to the author of this book, but does not possess the power to execute him, should report him to the people so

7 Carly-Sue,"1989: Death Threat Issued Against Rushdie - National Geographic Society,” laman sesawang National Geographic, dicapai 31 Januari 2014, http://www.nationalgeographic.org/thisday/feb14/death-threat-issued-against-rushdie/. 
that they may be punished for his actions. May peace and mercy of God and his blessings be with you?

Selepas fatwa tersebut dikeluarkan, telah menimbulkan keresahan yang teramat sangat kepada Salman Rushdie beserta orang-orang yang terbabit dengannya. Dan impak dari fatwa itu juga membuat umat Islam turut serta mencari dan berusaha melakukan kekacauan kepada penulis dan penerbitnya. Adapun keadaan Salman Rushdie selepas itu, ia disembunyikan oleh anggota polis selama lebih kurang sembilan tahun pada 30 kawasan yang berbeza-beza. ${ }^{9}$ Para ahli syarikat penerbitan buku terbabit seperti dilaporkan ada yang dibunuh dan dicederakan. ${ }^{10}$ Sehubungan dengan peristiwa tersebut, seorang penyelidik England, Jonathan Rauch menegaskan bahawa: ${ }^{11}$

The terrorism tactics that Khomeini encouraged and mobilized through the fatwa: "The valorization of suicide ("martyrdom"); the designation of civilians as combatants; the choice of a highly visible and symbolic target; the use of nongovernmental and civilian agents; perhaps above all, the capacity and determination to strike in cities and towns in the very heart of the West. The message to Westerners, not only to Rushdie, was: You are safe nowhere.

Kedua, kes pembunuhan Presiden Mesir, Anwar Sadat pada tahun 1981 yang berakibat daripadafatwa yang mengarahkan beliau dibunuh oleh Sheikh Omar Abdel Rahman, pemimpin tertinggi kumpulan Jama'at al-Jihad. ${ }^{12}$ Begitu juga peristiwa pengeboman bangunan New York World Trade pada tahun 1993 juga dikaitkan dengan fatwa tokoh ini. ${ }^{13}$ Seperti dilaporkan pada bulan April 2016, Mufti Besar Mesir Dr. Shawki Allam telah menemukan 3000 fatwa daripada orang yang bertanggungjawab yang menyeru agardilakukan pemusnahan ke atas beberapa gereja

8 Kenan Malik, From Fatwa to Jihad: The Rushdie Affair and Its Aftermath (Brooklyn: Melville House Publishing, 2009), 8.

9 "1989: Ayatollah Sentences Author to Death," laman sesawang BBC News, dicapai 14 Februari 2014, http:// news.bbc.co.uk/onthisday/ hi/ dates/stories/

10 Hugh Pope, "Muslim Mob Torches Hotel, Killing 35: Turkey: The Target Is the Translator of Rushdie's 'Satanic Verses'. He Escapes by Firefighters' Ladder," laman sesawangLos Angeles Times, July 3, 1993, bttp:/ / articles.latimes.com/1993-07-03/ news/mn-9699_1_satanic-verses.

11 Jonathan Rauch, "In Hind Sight, the War on Terror Began With Salman Rushdie," laman sesawang The Atlantic, dicapai 20 March 2015, https:/ / wnw.theatlantic.com/ magazine/ archive/2005/03/in-bindsight-the-war-on-terror-began-withsalmanrushdie/ 303854/.

12 Gabriel Weimann, "Cyber-Fatwas and Terrorism”, Studies in Conflict \& Terrorism 34, no. 10 (2011), 766.

13 Bruce Hoffman, Inside Terrorism (New York: Columbia University Press, 2006), 91. 
besar dan tempat bersejarah di Kaherah dan Giza. ${ }^{14}$ Ekoran kejadian tersebut, terdapat beberapa usaha pengeboman yang dilakukan di dua gereja besar di Mesir yang memakan korban lebih daripada 40 orang mangsa. ${ }^{15}$

\section{A1-Qaeda dan Penggunaan Fatwa}

Sudah umum diketahui bahawa golongan ekstrem agama (salafi jihadi) ${ }^{16}$ sememangnya menggunakan fatwa sebagai 'senjata' untuk menyokong dan menunjukkan keabsahan agenda perjuangan mereka. Antara kelompok pelampau agama yang mengamalkan konsep salafi jihadi ini ialah IS atau Daesh yang mana kelompok ini telah membuka lembaran baru pandangan dunia terhadap Islam, sekaligus mencetuskan 'Islamophobia'. Sebenarnya sebelum kemunculan kelompok ini, sejak serangan September 11, 2001, Islam dan penganutnya dikecam selain agama itu dipaksikan dalam segala hal berkaitan kemaraan terorisme.

Menguatkan lagi terhadap kenyataan di atas, seorang Pakar Kajian Strategik dan Keganasan Dr. Mohd. Mizan Mohd. Aslam berkata gerakan atau kumpulan itu mengamalkan fahaman 'Salafi Jihadi' yang menerima pakai pandangan tokoh Islam kontroversial Ibn Taimiyah. Pandangan Jihad dan Daulah Islamiyah tokoh itu kemudian dikembangkan kepada konsep jihad berdasarkan pandangan perjuangan Briged Abdullah Azzam, iaitu al-Qaeda di Lubnan, yang lebih menjurus kepada 'Jihad Takfiri', yang menggesa pengikut aliran itu melaksanakan jihad dengan cara kekerasan. ${ }^{17}$

14 Ashraf Abd al-Hameed, "In Egypt, '3000 Extremist Fatwas' Incite Destruction of Churches," laman sesawang al-Arabiya English, dicapai 1 April 2017, bttps://english.alarabiya.net/en/News/middleeast/2017/04/01/In-Egypt-3000-extremist-fatwas-incitedestruction-

15 "Twin ChurchBombings in Egypt Kill More than 40," laman sesawang CBC News, dicapai 9 April 2017, http:/ / www.cbc.ca/ news/ world/ egypt-church-bombing

16 Salafi (Bahasa Arab: سلفى) adalah pengikut gerakan Islam yang mengambil generasi pendahulu mereka yang salih, Salaf di zaman awal Islam, sebagai model teladan. Perkataan salaf merupakan kata nama Arab yang bermakna "pendahulu", atau "leluhur". Golongan ini juga dirujuk sebagai "Salaf al-Saleh", atau Leluhur Salih, dan merangkumi tiga generasi pertama Muslim: Sahabah, Tabi indanTabi" al-Tabi in. Tiga generasi ini dan pemahaman mereka terhadap teks dan rukun Islam dilihat oleh golongan Salafi sebagai faham ortodoks Islam, dan model bagaimana Islam harus diamalkan. Lihat "Salafi", laman sesawang Wikipedia, dicapai 24 April 2018, https:/ / ms.m.wikipedia.org

17 "Menelusuri Pemikiran Radikal Militan Daesh", Sinar Harian, 6 Februari 2017, bttp:/ / www.sinarbarian.com.my 
Jika ditelusuri lebih jauh, memang benarlah apa yang dikatakan oleh pakar di atas bahawa fatwa Ibn Taimiyah mengandungi kebenaran melakukan takfir dan memerangi musuh dan sekutunya. Asas utama pendekatan takfir ini ialah mengkafirkan puak lain yang bertentangan dengan pandangannya. Seperti contohnya, ia membezakan antara undang-undang Islam dan undang-undang buatan manusia. Umat Islam sejati wajib berhijrah ke kawasan Dar Islam (kerajaan yang mengamalkan undang-undang Islam).

Di sini Ibn Taimiyah membahagikan orang Kafir kepada tiga jenis: Pertama, penganut agama lain seperti Kristian. Umat Islam dibenarkan melakukan perjanjian damai dengan golongan ini. Kedua, golongan murtad seperti Parsi, Rom dan bangsa Arab yang murtad. Terhadap golongan ini tidak dibenarkan membuat perjanjian, seandainya mereka enggan bertaubat maka wajib diperangi. Ketiga, penganut Islam tetapi tidak mengerjakan taklif atau kewajipan agamanya, ini paling jahat dan wajib diperangi. ${ }^{18}$

Menurut IbnTaimiyah, konsep takfir dibahagi kepada 2 bentuk: Pertama, kegagalan mengerjakan taklif adalah satu kesalahan dan kedua, golongan ini lebih buruk daripada penganut bukan Islam. Sebab utama ia berbuat demikian oleh kerana suasana zamannya yang menyaksikan tentera Mongol memperkenalkan undangundang Yasa. ${ }^{19}$ Undang-undang tersebut menyatakan, walaupun mereka mendakwa beragama Islam tetapi tetap melakukan kemungkaran. Untuk itu ia mewajibkan memerangi golongan ini kerana mereka dikatakan paling jahat seperti khawarij. Konsep dar harb dan dar Islam yang disentuh oleh golongan Khawarij telah ditokoktambah oleh Ibn Taimiyah dengan konsep hijrah yang mewajibkan umat Islam berhijrah ke negara dar Islam. ${ }^{20}$

Kemudian fatwa kedua dikeluarkan oleh Osama bin Laden yang menyeru umat Islam untuk memerangi kuasa besar Amerika. Sebenarnya ia bukan dikatakan sebagai fatwa tetapi setakat pesanan Osama bin Laden. Namun begitu, isi pesanan ini didapati sangat berkesan mempengaruhi masyarakat awam. Apabila dikaji oleh

18 Ibn Taimiyyah, The Religious and Moral Doctrine of Jihad (Birmingham, England: Maktabah al-Ansar Publications, 2001), 8.

19 Denise Aigle, Mongol Empire Between Myth And Reality: Studies in Anthropological History(Leiden: E.J. Brill,2014), 301.

20 Ibid. 
ARTIKEL

penyelidik Barat, mereka mendapati Osama bin Laden berjaya meyakinkan umat Islam bahawa penentangan (aksi teroris) terhadap kuasaBarat dijustifikasikan sebagai suatu usaha jihad.

In invoking the support of the Muslim community, figures such as Osama bin Laden argue essentially that (1) Western powers are pursuing an imperialistforeign policy and oppressing Muslims in various parts of the world, (2) they are spreading immorality in the name of freedom and democracy, (3) corruptMuslim leaders are complicit in their efforts, and (4) good Muslims are required to resist theseforces, with violence and terrorism, if necessary. ${ }^{21}$

\section{Kekuatan Naratif Jihad al-Qaeda}

Seperti dimaklumi bahawa naratif jihad al-Qaeda dikira sangat berkesan sehingga diakui sendiri oleh Frank Ciluffo, bekas pengarah White House Homeland Security yang menegaskan:

We've been fighting the wrong battle. The real center of gravity of the enemy is their narrative".To win allies, you need an attractive product. In al Qaeda's case it is not its firepower but its narrative that attracts young people.

Kekuatan naratif jihad ini dapat dikesan oleh beberapa sebab utama:

Pertama, ia mempergunakan sumber ilmu Islam dengan kaedah yang sangat meyakinkan.Ia mengatakan: Al-Qaeda builds its political narrative on the religious tradition of Islam, appropriating and transforming key elements from the Qur'an and the Hadith, from Mohammed's life story and from the early history of Islam for its own ideological purposes. ${ }^{22}$

Kedua, ia mencapai status seni retorik yang dapat meyakinkan khalayak; According to Aristotle, rhetoric uses three intertwined techniques of persuasion: (i) Logos: using rational argumentation; (ii) Ethos: creating a trustworthy, authentic image, and (iii) Pathos: manipulating the emotions of the addressed audience.

Ketiga, kandungan asas naratif jihad global ini berkisar kepada beberapa perkara yang menyentuh hati dan emosi umat Islam:

1. Penderitaan umatIslam sedunia yang berlaku akibat kezaliman yang dilakukan gabungan kuasa tentera Salib iaitukuasa Zionis-Kristian. Kedua kuasa kafir ini

21 Osama bin Laden, "Declaration of War against the Americans Occupying the Land of the Two Holy Places," first published in London-based Al-Quds al Arabi, 1996.

22 Alex P. Schmid, "Al-Qaeda's "Single Narrative" and Attempts to Develop Counter-Narratives: The State of Knowledge”, ICCT Research Paper January 2014. 
memusnahkan semua asas Islam yang dibantukan kuat oleh pemerintah umat Islam sendiri.

2. Visi utama untuk melahirkan kerajaan Islam idaman terletak kepada kuasa khalifah Islamyang bakal menghapuskan sistem Barat dan menggantikannya dengan sistem perundangan Allah.

3. Jalan untuk menghapuskan kekejaman kuasa Barat hanya dapat direalisasikan melalui jalan jihad. Ia pasti terpaksa melalui pergorbanan yang tinggi tetapi bakal meraih kejayaan yang dijanjikan Allah termasuk mendapat status Syahid.

Keempat, penyebaran ideologi al-Qaeda ke seluruh duniadibuat dengan menggunakan saluran media dan internet; saluran yang memungkinkan ia mencapai tontotan dan bakal mendapat sokongan umat Islam sedunia.

Dalam soal penggunaan media penyebaran ini,ia telah diulas oleh pengkaji Barat dengan memetik surat Osama Bin Laden kepada Mullah Omar:

"It is obvious that the media war in this century is one of the strongest methods; in fact, its ratio may reach 90 per cent of the total preparation for the battles"23

Hal yang sama dipetik daripada surat Ayman al-Zawahiri kepada Abu Mus'ab Al-Zarqawi, pemimpin al-Qaeda di Iraq:

"I say to you: that we are in a battle and that more than half of this battle is taking place in the battlefield of the media. And that we are in a media battle in a race for the hearts and minds of our Ummab". ${ }^{24}$

Pengkaji Barat menyatakan bahawa naratif jihad al-Qaeda ini berjaya menarik masyarakat awam Islam di Timur Tengah (Tunisia, Mesir, Yemen dan Libya) sehingga mencetuskan fenomena Arab Spring. Mereka berjaya meyakinkanmasyarakat bahawa kaedahpemberontakan ketenteraan adalah satusatunya cara untuk memperbetulkan situasi anarki dinegara Islam.

Lebih meyakinkan lagi, proses menurunkan presiden Mohammed Mursi di Mesir yang dipilih melalui sistem demokrasi membuktikan bahawa sistem demokrasi

23 Document AFGP-2002-600321 in Harmony Database, US Department of Defense; Donald Holbrook, "Al-Qaeda Communiqués by Bin Laden and Al-Zawahiri: A Chronology", dalam Alex P. Schmid, The Routledge Handbook (2011), 280.

24 Ayman al-Zawahiri, Letter from al-Zawabiri to al-Zarqawi, Federation of American Scientists (Globalsecurity.com, 2005). Available online at bttp:/ / wnw.globalsecurity.org/security/library/report/2005/zawabiri-zarqawi-letter_9jul2005.htm. 
Barat memang tidak boleh dipercayai, dan sebagai gantinya konsep jihad bersenjata wajib dilakukan.

\section{Hasil dan Pembahasan}

\section{Fatwa Sebagai Alat Membendung Terorisme}

John L. Esposito adalah sarjana Barat yang terawal mencadangkan agar fatwa dijadikan sebagai alat membendung gejala terorisme. Hal ini ditegaskan oleh beliau apabila mengakaji sekitar 600 halaman fatwa bentuk ini yang dibantu oleh Muhammad Qadri pada tahun 2010. ${ }^{25}$

Seorang pengkaji Barat pakar tentang keganasan berpendapat, bahawa alat utama untuk menghadapi ekstremism agama hanya boleh dibuat oleh Sarjana Islam sendiri. Untuk itu, mufti Islam perlu mengetahui duduk perkara sebenar masalah ekstremism yang berkembang pada masa sekarang - sebelum mereka mampu melakukannya secara berkesan. Pengkaji Barat tersebut lebih lanjut mengatakan bahawa mereka boleh mengkaji, membuat pemetaan tentang kumpulan pengganas, tetapi mereka bersepakat menyatakan bahawa hanya sarjana Islam sahaja yang mampu menjawab ideologi pengganas. Hal ini sepertimana ditegaskan oleh Ed Husein, Quilliam's Co-Founder and Co-Director: ${ }^{26}$

Three benefits that prominent counter-terror fatwa citing scripture can do: First, it emboldens other Muslim thought leaders to amplify their voices against extremism. Secondly, it prevents activist Muslims from considering suicide bombers as "martyrs", and thus removes the hero status currently attached to murderers. And finally, a fatwa challenging perceived "martyrdom operations" will inject doubt into the minds of potential suicide bombers. Where there is doubt, in Islamic religious behavior, there is avoidance. Suicide bombers currently kill because they have certainty (yaqeen) of being rewarded in the next life (akbirah).

Berdasarkan hasil nasihat badan penasihat masyarakat Islam di Amerika, pihak berkuasa Amerika telah mula mengubah dasar memerangi keganasan di Amerika. Hasil daripada kajian proaktif, penyelidik Amerika telah mencadangkan agar:

25 Esposito, John L, What Everyone Needs to Know About Islam. 2nd ed (New York: Oxford University Press, t. th)166-67.

26 Ed Husain, "Fatwas Can Be a Force for Good," laman sesawang The Gaurdian, dicapai 26 February 2010, https:/ / www.theguardian.com 
Pertama: pihak kerajaan Amerika perlu mengubah dasar agar tidak menggunakan term ekstremis Islam melawan kuasa Barat. Islam tidak boleh dikaitkan kerana ia bakal menimbulkan kebencian umat Islam terhadap Barat. Ia perlu diubah dengan term ekstremism dinisbahkan pada tokoh pengganas tertentu.

Kedua: pihak kerajaan Amerika perlu mengubah dasar menzalimi tahanan suspek pengganas dengan menggunakan prinsip Islam kerana ia mencemarkan maruah Islam dan bakal menggagalkan usaha pemulihan.

In some notable cases, Islam has actually been exploited and misused as a tool by counterterrorism interrogators and law enforcement officials. For example, a number of reports have documented tactics used to intimidate, bumiliate, and threaten Muslim detainees by violating Islamic principles through impermissible exposure to nudity, improper physical contact with others, and mistreatment of the Qur'an. Some have argued that these methods were authorized by high-level policymakers. Needless to say, such tactics are not what this paper envisions when it seeks to deploy Islam as a counterterrorism tool. ${ }^{27}$

Dalam kajian Erik Saar dan Viveca Novak, ${ }^{28}$ didedahkan bagaimana kaedah penyeksaan berat yang dilakukan oleh pegawai penjara terhadap tahanan Islam:

US personnel ... routinely tempted detainees to look at pornographic magarines and videos, and used female interrogators, sometimes dressed provocatively, to violate Islamic strictures by rubbing against detainees and even leading one to believe he was being wiped with menstrual blood. ${ }^{29}$.

Ketiga: pihak Kerajaan perlu menjalinkan hubungan dengan sarjana dan masyarakat Islam dalam menghadapi ancaman pengganas. Hasilnya, dilaporkan bahawa pihak FBI telah menggunakan maklumat imigran Islam untuk menumpaskan beberapa cubaan keganasan. Bekas pendakwaraya pusat Larry Thompson melaporkan bahawa dengan bantuan maklumat imigran Islam, pada bulan September 2002, pihaknya berjaya menangkap 5 orang suspek penganas al-Qaeda di Lackawanna, New York. Ia menegaskan:

27 Jane Lampman, "Islam an Interrogation Tool: Need for Limits?" Christian Science Monitor, 2006.

28 Erik Saar dan Viveca Novak, Inside the Wire: a Military Intelligence Soldier's Eyewitness Account of Life at Guantanamo (New York: Penguin, 2005)

29 Captain James Yee, For God and Country: Faith and Patriotism Under Fire (New York: Perseus Books, 2005), 110-126. 
ARTIKEL

The Muslim community provided "extraordinary cooperation" and that "the assistance of Muslim-Americans in this case has helped to make the Buffalo community and our nation safer." 30

Dan dalam perkembangan lain, Rashad Hussain melaporkan: ${ }^{31}$

Law enforcement officials have also successfully recruited members of immigrant communities to serve as translators for the CLA and other intelligence agencies. In the summer of 2006, tips from the Muslim community uncovered a plot to blow up transatlantic airliners traveling from Europe to the United States.

Keempat: pemerintah Barat sepatutnyamenggunakan fatwa ulama Islamuntukmengatasi ekstremism Islam. Hasilnya, pihak kerajaan telah mempergunakan fatwa yang dikeluarkan oleh the Fiqh Council of North America berbunyi:

We have consistently condemned terrorism and extremism in all forms and under all circumstances, and we reiterate this unequivocal position. Islam strictly condemns religious extremism and the use of violence against innocent lives. There is no justification in Islam for extremism or terrorism. Targeting civilians' life and property through suicide bombings or any other method of attack is haram probibited in Islam and those who commit these barbaric acts are criminals, not 'martyrs.' In the light of the teachings of the Qur'an and Sunnab we clearly and strongly state: All acts of terrorism targeting the civilians are haram (forbidden) in Islam. It is haram for a Muslim to cooperate or associate with any individual or group that is involved in any act of terrorism or violence. It is the duty of Muslims to cooperate with the law enforcement authorities to protect the lives of all civilians. $^{32}$

Selain itu, fatwa yang dikeluarkan oleh 500 ulama British juga disebarkan.

Isinya menyentuh;

"Islam strictly, strongly and severely condemns the use of violence and the destruction of innocent lives. There is neither place nor justification in Islam for extremism, fanaticism or terrorism. Suicide bombings, which killed and injured innocent people in London, are haram vehemently prohibited in Islam, and those who committed these barbaric acts in London [on July 7, 2005] are criminals not martyrs. Such acts, as perpetrated in London, are crimes against all of humanity

30 News Conference of Larry Thompson, Robert Mueller, \& George Pataki (Sept. 14, 2002), LEXIS News Library, FDCH Political Transcripts File (remarks of Larry Thompson, Deputy Attorney General).

31 Rashad Hussain (2008), Reformulating the Battle of Ideas: Understanding the Role of Islam in Counterterrorism Policy, analysis paper Number 13 (The Brookings Project on U.S. Relations with the Islamic World, 2008), 1-21.

32 "Fatwa by U.S. Muslims against Religious Extremism", July 25, 2005, avail. at http://www.cfr.org/publication/15808/fatwa_against_terrorism.html 
and contrary to the teachings of Islam. ... The Holy Quran declares: Whoever kills a buman being... then it is as though he has killed all mankind; and whoever saves a buman life, it is as though he had saved all mankind.' (Quran, Surah al-Maidah (5), verse 32) Islam's position is clear and unequivocal: Murder of one soul is the murder of the whole of humanity; he who shows no respect for buman life is an enemy of humanity." 33

Fatwa Mufti Saudi turut digunakan, yang menjelaskan:

What is happening in some countries from the shedding of the innocent blood and the bombing of buildings and ships and the destruction of public and private installations is a criminal act against Islam. .. . Those who carry out such acts have the deviant beliefs and misleading ideologies and are responsible for the crime. Islam and Muslims should not be beld responsible for such actions." 34

Abdul Aziz bin Abdallah Al-Shaykh, ketua Mufti Arab Saudi juga menerangkan:

Firstly: the recent developments in the United States including bijacking planes, terrorizing innocent people and shedding blood, constitute a form of injustice that cannot be tolerated by Islam, which views them as gross crimes and sinful acts. Secondly: any Muslim who is aware of the teachings of his religion and who adheres to the directives of the Holy Qur'an and the Sunnab (the teachings of the Prophet Muhammad) will never involve bimself in such acts, because they will invoke the anger of God Almighty and lead to harm and corruption on earth.

Terpenting sekali, pandangan al-Shaykh Muhammad Afifi al-Akiti, ulama Malaysia yang berkhidmat di Pusat Studi Islam Oxford University turut digunakan untuk menolak ekstremisme agama. Isinya menyentuh:

It is truly sad that despite our sophisticated and elaborate set of rules of engagement and in spite of the strict codes of warfare and the chivalrous disciplines which our soldiers are expected to observe, all having been thoroughly worked out and codified by the orthodox jurists of the Umma from among the generations of the Salaf, there are today in our midst those who are not ashamed to depart from these sacred conventions in favor of opinions espoused by persons who are not even trained in the Sacred Law at all let alone enough to be a Qadi or a Faqib — the rightful heir and source from which they should receive practical guidance in the first place.Instead they rely on engineers or scientists and on those who are not among its abl yet speak in the name of our Law. With these "reformist" preachers and da'i comes a departure from the traditional ideas about the rules of

33 British Muslim Forum, press release of July 18, 2005, avail. athttp:/ / www.britishmuslimforum.org/view_press_release.php? $i d=26$.

34 Public Statements by Senior Saudi Officials Condemning Extremism and Promoting Moderation," May 2004, bttp:// wmw.saudiembassy.net/ReportLink/Report ExtremismMay04.pdf, page 10

35 Mufti 'Abdul Aziz bin 'Abdallah al-Ashaykh, Statement of September 15, 2001, avail. at bttp:/ / www.saudiembassy.net/ 
Siyar/Jihad/Qital, i.e., warfare. Do they not realize that by doing so and by following them they will be ignoring the limitations and restrictions cherished and protected by our pious forefathers and that they will be turning their backs on the Jama'a and Ijma' and that they will be engaging in an actfor which there is no accepted legal precedent among the orthodoxy in our entire history? Have they forgotten that part of the original maqsad of warfare/jihad was to limit warfare itself and that warfare for Muslims is not total war, so that women, children and innocent bystanders are not to be killed and property not to be needlessly destroyed? To put it plainly, there is simply no legal precedent in the history of Sunni Islam for the tactic of attacking civilians and overtly non-military targets. ${ }^{36}$

Oleh yang demikian jika dilakukan analisa terhadap kesemua fatwa ini, kita akan mendapati beberapa perkara utama:

1. Kutukan kepada pengunaan kaedah kekerasan yang bertentangan dengan citra perdamaian Islam.

2. Pengharaman bom bunuh diri dan larangan menjadikan orang awam sebagai mangsa.

3. Fatwa atau pandangan yang dibuat oleh golongan ekstrem bukan datang daripada ulama yang berautoriti tetapi daripada golongan bukan ulama.

4. Mendedahkan kelemahan tafsir golongan ekstrem tentang konsep jihad yang salah dan tidak mengambilkira elemen konstekstual ayat al-Quran diturunkan.

\section{Ulasan Terhadap Fatwa Counterteroris}

Nina Karimi seorang penyelidik Barat mendapati setakat ini fatwa yang dikeluarkan oleh ulama Islam ternyata gagal dipergunakan sepenuhnya. ${ }^{37}$ Ini disebabkan oleh beberapa perkara:

Pertama, autoriti Mufti dipertikaikan - dianggap pro pemerintahdan kuasa Barat. Apatah lagi dalam idealism salafi jihad secara terang-terangan mengklasifikasikan ulama pro kerajaan tohgut sebagai kafir.

Bagi al-Qaeda, masyarakat zaman moden terbahagi kepada 4 jenis: ${ }^{38}$

36 Defending the Civilians: Mudafi' al-Mazlum, Shaykh Muhammad Afifi al-Akiti's Fatwa on Suicide Bombings," avail. at http://www.masud.co.uk/ISLAM/misc/defending_civilians.htm.

37 Nina Karimi, Fatwa'sagainst Terrorism and Terrorist Organizations: an Examination of a Potential Counter-Terrorism Tool. Tesis Sarjana (Canada:the University of Waterloo, 2017).

38 Mohammed M. Hafez, "Tactics, Takfir, And Anti-Muslim Violence", dalam Assaf Moghadam And Brian Fishman, Self-Inflicted Wounds: Debates And Divisions Within Al-Qaeda And Its Periphery, Harmony Project Combating Terrorism Center At West Point (December 16, 2010), 22. 
1. Pemerintah toghut dari kalangan umat Islam yang tidak menerimapakai sistem shari'ah Islam. Mereka bukan lagi tergolong dalam kategori umat Islam dan jenayah utama mereka ialah menentang serta menzalimi penganut Islam yang ingin melaksanakan shari'ah Islam dalam kehidupan bernegara.

2. Golongan murtad yang menentang prinsip al-Wala' wa al-Bara' (taat kepada Islam dan membebaskan diri daripada golongan kafir). Mereka berkerjasama dengan kuasa kafir luar. Ia terdiri daripada anggota keselamatan, kakitangan kerajaan, polis dan semua pihak yang ingin mengekalkan kerajaan toghut sama ada secara langsung mahupun tidak langsung.

3. Golongan sesat dan mushrik yang melanggar prinsip tauhid yang dibawa oleh ulama ortodoks Sunni. Apa yang lebih penting, ia bertentangan dengan apa yang dibawa oleh golongan salafi dan wahabi. Label ini diberikan khusus kepada golongan Syi'ah dan Baha’i di Iran, Ahmadi di Pakistan dan Sufi di kebanyakan dunia Islam.

4. Penganut Islam sejati yang menyokong usaha golongan ekstrem. Mereka juga tidak menyokong pemerintah toghut dan menjauhkan diri daripada terpengaruh dengan aktiviti kebudayaan barat. Golongan ini merujuk kepada masyarakat sunni di kebanyakan dunia Islam.

Kedua, fatwa ini kurang mendapat pendedahan global dan secara online sedangkan fatwayang pro ekstrem lebih mudah diperolehi.

Ketiga, isi fatwa terlalu umum dan tidak menjawab kesemua hujjah ayat alQur'an yang membenarkan jihad ekstrem melawan kuasa Barat yang menindas umat Islam. Fatwa ini lebihmenekankan fakta bahawa Islam menyeru ke arah perdamaian semata. Ia sama sekali tidak mengkritik dasar kerajaan Barat yang menindas umat Islam.

After examining counter-terror fatwas, the vast majority only cite Qur'an verses that only present Islam as a religion of peace to justify their position. Yet, these Qur'an verses that present Islam as a religion of peace have conditions and limitations, and are neither unequivocal nor absolute pronouncements of peace. Moreover, the counter-terror fatwas never mention, and do not challenge, the specific Qur'anic verses that endorse violence. Because of this omission, these counter-terror fatwas are unable to challenge directly, and hence potentially disrupt, the ideological core of Islamist terrorism. 
Nina Karimi bersama dengan Donald Holbrook $^{39}$ telah mengenalpasti terdapat 10 ayat al-Qur'an yang pro jihad yang gagal dijawab oleh mufti-mufti Islam. Ianya terdiri daripada;

1. An-Nisā (4): 74-76

2. An-Nisā (4): 84;

3. At-Taubah (9): 5 ;

4. At-Taubah (9): 38-39;

5. At-Taubah (9): 111;

6. At-Taubah (9): 13-15;

7. Al-Baqarah (2): 190-191;

8. Al-Baqarah (2): 216 ;

9. Al-Hajj (22): 39-40;

10. Al-Anfāl (8): 39.

Keempat,terdapat percanggahan antara fatwa ulama Islam sendiri, seperti fatwa Yusuf al-Qardawi yang membenarkan jihad bom bunuh diri untuk masyarakat Palestin dengan fatwanya yang mengutuk peristiwa 11/9.

Kelima, fatwa pro Amerika dan pemerintah Islam bertentangan dengan realiti umat Islam semasa. Apabila dinilai mengikut realiti semasa, didapati umat Islam awam bersetuju dengan tindakan Amerika yang menindas umat Islam. Buktinya terdapat sokongan masyarakat awam Islam dinegara Muslim bahawa mereka menganggap penguasaAmerika sebagai musuh yang ingin memusnahkan Islam.

\section{Kesimpulan}

Sejarah membuktikan bahawa fatwa memang berperanan besar dalam menyelesaikan masalah umat Islam. Ia telah dipergunakan sepenuhnya oleh pihak ekstremis agama untuk meraih sokongan daripada umat Islam. Dalam perkembangan semasa, didapati bahawa pihak Barat turut mempergunakan institusi fatwa ini untuk membendung gerakan terorism. Namun begitu, masih lagi terdapat kelemahan fatwa kounterteroris ini yang wajib diperbetulkan. Antaranya ia dibuat seolah-olah

39 Donald Holbrook, "Using the Qur'an to Justify Terrorist Violence: Analyzing Selective Application of the Qur'an in English-Language Militant Islamist Discourse," Perspectives on Terrorism 4, No. 3 (2010), bttp:/ / www.terrorismanalysts.com/ 
ARTIKEL

mengharam aktiviti ekstremism Islam tetapi sebaliknya mendiamkan diri terhadap aktiviti ekstremism kuasa Barat. Begitu juga fatwa kounter teroris gagal menjawab secara tuntas 10 ayat al-Qur'an yang digunakan oleh golongan ekstremis.

\section{DAFTAR PUSTAKA}

"1989: Ayatollah Sentences Author to Death," websiteBBC News, dicapai 14 Februari 2014, http://news.bbc.co.uk/onthisday/hi/dates/stories/

"Fatwa by U.S. Muslims against Religious Extremism”, July 25, 2005, avail. at http://www.cfr.org/publication/15808/fatwa_against_terrorism.html

“Menelusuri Pemikiran Radikal Militan Daesh", Sinar Harian, 6 Februari 2017, http://www.sinarharian.com.my

"Public Statements by Senior Saudi Officials Condemning Extremism and Promoting Moderation,” May 2004, http://www.saudiembassy.net/ReportLink/ Report Extremism May 04.pdf.

“Salafi”, websiteWikipedia, dicapai 24 April 2018, https://ms.m.wikipedia.org

“Twin ChurchBombings in Egypt Kill More than 40," websiteCBC News, dicapai 9 April 2017, http://www.cbc.ca/news/world/egypt-church-bombing

Abdullah, Auni Haji.Hisbah Dan Pentadbiran Negara (Kuala Lumpur: IKDAS, 2000).

Aigle, Denise.Mongol Empire Between Myth And Reality: Studies in Anthropological History (Leiden: E.J. Brill, 2014).

al-Ashaykh,Mufti 'Abdul Aziz bin 'Abdallah. Statement of September 15, 2001, avail. at http://www.saudiembassy.net/

Al-Hameed, Ashraf Abd. "In Egypt, '3000 Extremist Fatwas' Incite Destruction of Churches," websiteal-Arabiya English, dicapai 1 April 2017, https://english.alarabiya.net/en/News/middle-east/2017/04/01/In-Egypt3000-extremist-fatwas-incitedestruction-

Al-Zawahiri, Ayman.Letter from al-Zawahiri to al-Zarqawi, Federation of American Scientists (Globalsecurity.com, 2005). Available online at http://www.globalsecurity.org/security/library/report/2005/zawahirizarqawi-letter_9jul2005.htm.

Awang, Ramli.Tasawwur Rabbani Menurut al-Quran Dan Sunnah (Kuala Lumpur: Hidayah Publisher, 1997).

Bakar, Mohd Daud, "Instrumen Fatwa Dalam Perkembangan Perundangan Islam", Jurnal Syariah 1, jilid 5, (1997).

British Muslim Forum, press release of July 18, 2005, avail. at http://www.britishmuslimforum.org/view_press_release.php?id=26. 
Carly-Sue,"1989: Death Threat Issued Against Rushdie - National Geographic Society," websiteNational Geographic, dicapai 31 Januari 2014, http://www.nationalgeographic.org/thisday/feb14/death-threat-issuedagainst-rushdie/.

Defending the Civilians: Mudafi' al-Mazlum, Shaykh Muhammad Afifi al-Akiti's Fatwa on Suicide Bombings," avail. at http://www.masud.co.uk/ISLAM/misc/defending_civilians.htm.

Document AFGP-2002-600321 in Harmony Database, US Department of Defense.

Esposito, John L, What Everyone Needs to Know About Islam. 2nd ed (New York: Oxford University Press, t. t.).

Hafez, Mohammed M. "Tactics, Takfir, And Anti-Muslim Violence", dalam Assaf Moghadam And Brian Fishman, Self-Inflicted Wounds: Debates And Divisions Within Al-Qaeda And Its Periphery, Harmony Project Combating Terrorism Center At West Point (December 16, 2010).

Hoffman, Bruce.Inside Terrorism (New York: Columbia University Press, 2006).

Holbrook, Donald. "Al-Qaeda Communiqués by Bin Laden and Al-Zawahiri: A Chronology", dalam Alex P. Schmid, The Routledge Handbook (2011).

Holbrook, Donald. 'Using the Qur'an to Justify Terrorist Violence: Analyzing Selective Application of the Qur'an in English-Language Militant Islamist Discourse," Perspectives on Terrorism 4, No. 3 (2010), http://www.terrorismanalysts.com/

Husain, Ed. "Fatwas Can Be a Force for Good," websiteThe Gaurdian, dicapai 26 February 2010, https://www.theguardian.com

Hussain, Rashad (2008), Reformulating the Battle of Ideas: Understanding the Role of Islam in Counterterrorism Policy, analysis paper Number 13 (The Brookings Project on U.S. Relations with the Islamic World, 2008).

Karimi, Nina.Fatwa's against Terrorism and Terrorist Organizations: an Examination of a Potential Counter-Terrorism Tool. Tesis Sarjana (Canada: the University of Waterloo, 2017).

Lampman, Jane. "Islam an Interrogation Tool: Need for Limits?” Christian Science Monitor, 2006.

Majid, Mahmood Zuhdi Abd. Bidang Kuasa Jenayah Mahkamah Syariah di Malaysia (Kuala Lumpur: Dewan Bahasa dan Pustaka, 2001).

Malik, Kenan.From Fatwa to Jihad: The Rushdie Affair and Its Aftermath (Brooklyn: Melville House Publishing, 2009).

News Conference of Larry Thompson, Robert Mueller, \& George Pataki (Sept. 14, 2002), LEXIS News Library, FDCH Political Transcripts File (remarks of Larry Thompson, Deputy Attorney General). 
Osama bin Laden, "Declaration of War against the Americans Occupying the Land of the Two Holy Places," first published in London-based Al-Quds al Arabi, 1996.

Pope, Hugh. "Muslim Mob Torches Hotel, Killing 35: Turkey: The Target Is the Translator of Rushdie's 'Satanic Verses'. He Escapes by Firefighters' Ladder,' websiteLos Angeles Times, July 3, 1993, http://articles.latimes.com/1993-0703/news/mn-9699_1_satanic-verses.

Rahman, Mohammad Taufiq. Social Justice in Western and Islamic Thought: A Comparative Study of John Rawl's and Sayyid Qutb's Theories of Social Justice. Diss. Jabatan Akidah dan Pemikiran Islam, Akademi Pengajian Islam, Universiti Malaya, 2010.

Rauch, Jonathan. "In Hind Sight, the War on Terror Began With Salman Rushdie," websiteThe Atlantic, dicapai 20 March 2015, https://www.theatlantic.com/magazine/archive/2005/03/in-hindsight-thewar-on-terror-began-with-salmanrushdie/ 303854/.

Saar, Erik dan Viveca Novak, Inside the Wire: a Military Intelligence Soldier's Eyewitness Account of Life at Guantanamo (New York: Penguin, 2005)

Schmid, Alex P. "Al-Qaeda's "Single Narrative" and Attempts to Develop CounterNarratives: The State of Knowledge", ICCT Research Paper January 2014.

Taimiyyah, Ibn.The Religious and Moral Doctrine of Jihad (Birmingham, England: Maktabah al-Ansar Publications, 2001).

Weimann, Gabriel. "Cyber-Fatwas and Terrorism", Studies in Conflict \& Terrorism 34, no. 10 (2011).

Yee, Captain James.For God and Country: Faith and Patriotism Under Fire (New York: Perseus Books, 2005). 